\title{
Article
}

\section{Impact of Dietary Supplementation of Flaxseed Meal on Intestinal Morphology, Specific Enzymatic Activity, and Cecal Microbiome in Broiler Chickens}

\author{
Roua Gabriela Popescu ${ }^{1}$, Sorina Nicoleta Voicu ${ }^{1,2, *}$, , Gratiela Gradisteanu Pircalabioru ${ }^{3}$, Sami Gharbia ${ }^{1,4}$,

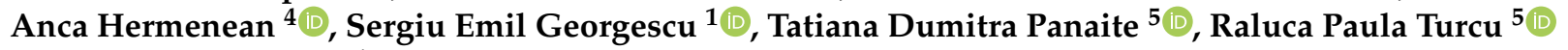 \\ and Anca Dinischiotu ${ }^{1}$
}

check for updates

Citation: Popescu, R.G.; Voicu, S.N.; Gradisteanu Pircalabioru, G.;

Gharbia, S.; Hermenean, A.; Georgescu, S.E.; Panaite, T.D.; Turcu, R.P.; Dinischiotu, A. Impact of Dietary Supplementation of Flaxseed Meal on Intestinal Morphology, Specific Enzymatic Activity, and Cecal Microbiome in Broiler Chickens. Appl. Sci. 2021, 11, 6714. https://doi.org/ 10.3390/app11156714

Academic Editor:

Wojciech Kolanowski

Received: 4 June 2021

Accepted: 20 July 2021

Published: 22 July 2021

Publisher's Note: MDPI stays neutral with regard to jurisdictional claims in published maps and institutional affiliations.

Copyright: (C) 2021 by the authors Licensee MDPI, Basel, Switzerland. This article is an open access article distributed under the terms and conditions of the Creative Commons Attribution (CC BY) license (https:/ / creativecommons.org/licenses/by/ $4.0 /)$.
1 Department of Biochemistry and Molecular Biology, Faculty of Biology, University of Bucharest, 050095 Bucharest, Romania; roua.popescu@drd.unibuc.ro (R.G.P.); samithgh2@hotmail.com (S.G.); sergiu.georgescu@bio.unibuc.ro (S.E.G.); anca.dinischiotu@bio.unibuc.ro (A.D.)

2 Department of Pharmacy, Faculty of Pharmacy, Titu Maiorescu University, 004051 Bucharest, Romania

3 Department of Botany-Microbiology, The Research Institute of the University of Bucharest (ICUB), 076201 Bucharest, Romania; gratiela.gradisteanu@icub.unibuc.ro

4 Department of Experimental and Applied Biology, "Aurel Ardelean” Institute of Life Sciences, Vasile Goldis Western University of Arad, 310414 Arad, Romania; anca.hermenean@gmail.com

5 National Research and Development Institute for Animal Biology (IBNA Balotești), 077015 Ilfov, Romania; tatiana_panaite@yahoo.com (T.D.P.); raluca.socoliuc@yahoo.com (R.P.T.)

* Correspondence: sori.petrache@yahoo.com; Tel.: +40-21-318-1575

\begin{abstract}
The use of natural feed additives could be a beneficial approach to maintaining the health of chickens and a way to improve food digestion. Flaxseed is a rich source of omega-3 fatty acid, alpha linolenic acid, oleic acid, and fiber. The purpose of this study was to evaluate the effects of dietary inclusion of $4 \%$ flaxseed on the intestinal morphology, specific enzymatic activity, and cecal microbiome in broiler chickens. The 4-week feeding trial was conducted on 100 Cobb 500 (14 days of age) unsexed broiler chickens divided into two groups: a control group (C) and an experimental group (E). The broilers were housed in boxes of size $3 \mathrm{~m}^{2}$ (each group was housed in a single box with 10 replicates, 5 chickens per replicate) and reared on permanent wood shaves litter $(10-12 \mathrm{~cm}$ thick). At the end of the experiment, chickens $(n=10)$ were sacrificed and tissue samples were harvested from the duodenum, jejunum, and cecum for histological, enzymatic, and microbiome analyses. In group E, histological analysis revealed a significant increase in villus height $(p<0.001)$ possibly leading to enhanced intestinal nutrient absorption. An increase in the specific activities of $\alpha$-amylase $(p<0.05)$, invertase $(p<0.01)$, and endo- $\beta-1,4$-glucanase $(p<0.001)$ was noticed in the E group for the duodenum and jejunum compared to the control group. In contrast, maltase activity decreased in the duodenum and increased in the jejunum in the E group. The trypsin and lipase specific activities did not vary in a significant way. In addition, the cecal microbiome of the E group was characterized by an increase in Lactobacilli $(p<0.01)$ and Clostridium coccoides and a decrease in Bacteroides, Ruminoccocus, Enterobacteriaceae, and Clostridium leptum. In conclusion, our results suggest that dietary supplementation of flaxseed meal may boost intestinal health status in poultry.
\end{abstract}

Keywords: flaxseed meal; poultry; digestive enzyme activities; nutrition; microbiome

\section{Introduction}

At a global level, poultry meat is a mass consumer product. Among the industrialized Western countries, the United States and the members of the European Union are among the highest poultry consumers [1]. Poultry are commonly the most prevalent livestock in resource-poor areas and contribute to food security in world meat production through the supply of nutrient-rich products [2]. Cost efficiency is pivotal in poultry production; therefore, it is desirable not to include antibiotics in the diet because their use in both 
humans and animals contributes to the increasing resistance of microorganisms to these therapeutic agents $[3,4]$.

The Cobb 500 hybrid is the most widely used in industry and is also the broiler with the earliest growing time and the best feed conversion rate. It is appreciated due to its superior productive performance in conditions with low nutrient density [5].

Macronutrients in the diet of birds are represented by monosaccharides, monoglycerides, amino acids, free fatty acids, and dipeptides, all of which can be absorbed [6]. High growth rate and feed efficiency are crucial aims to be achieved in poultry production [7]. Several aspects should be considered for the optimum performance of birds, including weight gain, genetic potential, diet quality, feed intake, feed conversion ratio, disease status, and environmental conditions [8,9]. Apart from these mentioned factors, a well-functioning and healthy gut is essential in poultry production, improving nutrient digestion, absorption, metabolism, and overall health and growth performance [10]. When gut homeostasis is disturbed, digestion and nutrient absorption are impaired, impairing the health and performance of birds $[9,11]$.

Recent studies indicate that the nutritional quality of feed used in poultry farming is correlated with the activity of digestive enzymes [12]. In birds, the proventriculus/gizzard participates in grinding and mixing ingested feed to facilitate the activity of endogenous enzymes; therefore, the gastrointestinal tract of poultry produces enzymes to aid in the digestion of nutrients $[13,14]$. Nutrients from the diet are absorbed along the gastrointestinal tract through the intestinal mucosa, folded into villi and polarized epithelial cells that are present on the apical domain of the microvilli forming the brush border. This enhances the small intestinal surface by around 600 -fold, leading to higher capacity for nutrient absorption [12,15].

Among the determinants that may be involved in the gut health and performance of chickens, the commensal microbiome is of paramount importance due to its multiple roles in host physiology, including the maturation of the immune system and protection against pathogenic microorganisms [10,16]. Previously, it was suggested that the gut microbial profile can be shaped by changes in the host diet [17]. In addition to these, some feed or feed ingredients, referred to as nutraceuticals, have been shown to generate protective effects on the intestinal tract of chickens by modulating the microbiome and the immune system $[9,18]$.

In broiler nutrition, probiotic species such as Bifidobacterium, Lactobacillus, Streptococcus, Enterococcus, Bacillus, Candida, Saccharomyces, and Aspergillus are used to improve broilers' growth performance and counteract infections [19-21].

Phytogenic feed additives (PFA) are plant-derived natural bioactive compounds that are incorporated into animal feed to enhance productivity [22,23].

In recent years, PFAs have been employed as natural growth promoters in the poultry and pig industries [24]. Flaxseeds contain about $34 \%$ oil and $50 \% \alpha$-linolenic acid, and they are a common feed ingredient in poultry diets. Due to their rich content in omega-3 fatty acids, they represent an increasingly popular additive to the diets of many consumers $[25,26]$. Also, they contain some anti-nutritional factors, such as cyanogenic glucosides and mucilage, which can reduce the enzymatic activity of the pancreas, leading to decreased digestion and lower bird performance [27].

Flaxseed and flaxseed meal have been shown to promote several health benefits, including anticancer effects, antimicrobial activity, immunomodulation, laxative effects, and reduction of atherogenic risks [28,29]. In brown layer hens' diets, the inclusion of flaxseed meal reduced crude protein digestibility and apparent metabolizable energy corrected for nitrogen (AMEn), while egg production and hen performance increased [30,31]. Compared to laying hens, broiler chickens fed a flaxseed diet exhibited negative effects on production performance due to anti-nutritional factors (ANFs) that interfered with nutrients used, with an impact on the birds' performance parameters, including final body weight, average daily gain, yield of cut-up parts, and carcass weight [32]. However, poultry fed a $10 \%$ 
flaxseed diet for $24 \mathrm{~h}, 4-5$ days before slaughter, showed polyunsaturated fatty acid (PUFA) enrichment of the carcass, without any effect on body weight $[32,33]$.

In poultry, the site of nutrient absorption is in the small intestine, especially the duodenum and jejunum segments. Recent studies have shown that non-starch polysaccharides from flaxseed have decreased nutrient digestibility and have a negative impact on productive performance [34], whereas carbohydrate hydrolyzing enzymes improve the digestibility of poultry diets [35]. The capacity for nutrient absorption at the intestinal level depends on the gastrointestinal tract's mucosal surface area and the functional properties of the epithelium [36].

Previously, it was shown that flaxseed meal administration decreased chicken meat cholesterol [37] and improved the egg nutritional quality by increasing the yolk PUFA content [38].

The aim of this study was to evaluate the effects of the presence of flaxseed meal as a source of PUFAs in the conventional diet of Cobb 500 broiler chickens on digestive health by histologic and morphometric analyses of the intestinal mucosa, analysis of the cecal microbiome, and specific enzymatic activity measurements of lipase, trypsin, alpha-amylase, invertase, maltase, and endo- $\beta-1,4$-glucanase.

\section{Materials and Methods}

\subsection{Plant Material and Proximate Chemical Composition and Fatty Acid Profiles}

Phytochemical characterization of plant material samples of flaxseed meal (Linum usitatissimum L.) was performed by a commercial company producing cold-pressed oils on the local market in Alexandria (Teleorman, Romania). The proximate chemical composition determinations were performed using methods from Regulation (CE) no. 152/2009 (Sampling and analytical methods for the official inspection of feeds): the Kjeldahl method (SR EN ISO 5983-2:2009) for crude protein (CP); the gravimetric method (SR ISO 6496:2001) for dry matter (DM); extraction in organic solvents (SR ISO 6492:2001) for ether extractives (EE); the gravimetric method (SR EN ISO 2171:2010) for ash (Ash); and acid hydrolysis followed by alkaline hydrolysis (SR EN ISO 6865:2002) for crude fiber (CF).

The fatty acid content was assessed via fatty acid methyl ester (FAME) gas chromatography according to ISO/TS 17764-2 (2008), as described by Panaite et al. [39]. In brief, fatty acids from the total lipid extracts were converted to methyl esters by transesterification (in methanol containing 3\% concentrated $\mathrm{H}_{2} \mathrm{SO}_{4}$, for $4 \mathrm{~h}$ at $80{ }^{\circ} \mathrm{C}$ ). Methyl esters of fatty acids were evaluated in a Perkin Elmer-Clarus 500 chromatograph equipped with a flame ionization detector (FID) fitted with a BPX70 capillary column $(60 \mathrm{~m} \times 0.25 \mathrm{~mm}$ i.d., $0.25 \mu \mathrm{m}$ film thickness). The column temperature was programmed at $5^{\circ} \mathrm{C} / \mathrm{min}$ from $180{ }^{\circ} \mathrm{C}$ to $220^{\circ} \mathrm{C}$. The carrier gas was hydrogen $\left(35 \mathrm{~cm} / \mathrm{s}\right.$ linear velocity at $\left.180{ }^{\circ} \mathrm{C}\right)$ and the splitting ratio was 1:100. The injector and detector temperatures used were $250{ }^{\circ} \mathrm{C}$ and $260{ }^{\circ} \mathrm{C}$, respectively. FAME identification was performed by comparison with the retention times of the standards, and the results are expressed as grams of fatty acid per $100 \mathrm{~g}$ of total fatty acids.

\subsection{Poultry and Experimental Treatments}

The 4-week feeding trial was conducted on 100 Cobb 500 broilers (14 days of age), assigned to 2 groups, housed in boxes of size $3 \mathrm{~m}^{2}$ (50 chickens per group, 10 replicates, with 5 chickens per replicate) and housed in an experimental hall on permanent wood shaves litter in a controlled microclimate according to the Cobb 500 Management Breeding Guide. The broilers were procured from a commercial hatchery at 1 day old. During the starter stage (1-14 days) all chicks received a conventional diet formulation (based on corn, gluten, and soybean meal) with $23 \% \mathrm{CP}$ and $3039.79 \mathrm{kcal} / \mathrm{kg}$ ME. After 14 days, the broilers were individually weighed and assigned to one of two groups: a control group (C), fed the conventional diet, and an experimental group (E), fed the conventional diet supplemented with $4 \%$ flaxseed meal (experimental diet structure published previously by Turcu et al. [40]). Diet formulations were calculated to meet the feeding requirements of 
broiler chickens as given by the NRC [41]. Throughout the experimental period (14-42 days, broiler age) the following parameters were monitored: body weight (grams); average daily feed intake (grams of feed per broiler per day); average daily weight gain (grams per broiler per day); and feed conversion ratio. They had free access to feed and water. At the end of the experimental period (42 days), 10 broilers per group (randomly selected) were electrically stunned and subsequently slaughtered by cervical dislocation, according to the Romanian Law 43/2014 for the handling and protection of animals used for experimental purposes (EU Council Directive 98/58/EC and Directive 2010/63/EU). After slaughtering the broiler chickens. samples from intestinal contents from the distal portion of the duodenum and jejunum were collected in order to perform enzymatic analysis (alpha-amylase, trypsin, and endo- $\beta$-1,4-glucanase); samples from the intestinal wall of the distal portion of the duodenum and jejunum were collected in order to perform enzymatic analysis (invertase and maltase) and histologic analyses; and samples from the cecal intestinal content were collected in order to perform microbiome characterization, according to Popescu et al. [12].

\subsection{Histology}

The fragments of the duodenum and jejunum were fixed in $4 \%$ paraformaldehyde solution in PBS for $24 \mathrm{~h}$, followed by dehydration in a graded series of alcohols, clarification in toluene, and embedding in paraffin. Sections of $4 \mu \mathrm{m}$ thickness were adhered on slides and stained with hematoxylin-eosin (H\&E) and Alcian Blue pH 2.5 (AB). Histomorphometry of the intestinal segments was performed on ten villi and crypts per individual using an optical microscope (Olympus BX43, Tokyo, Japan), a camera (30 XC Olympus, Tokyo, Japan), and the image analysis software Olympus Cell Dimension. The following variables (randomly selected) were measured in each segment: villus height (villus tip to base of villus) and crypt depth (based of villus to bottom of crypt). An average value for each variable was calculated for each intestinal segment of each bird.

\subsection{Enzymatic Analysis}

Alpha-Amylase (EC 3.2.1.1) activity was quantified using a modified version of the protocol by Bernfeld [42] in a reaction mixture with a final volume of $405 \mu \mathrm{L}$. Trypsin (EC 3.4.21.4) activity was assayed according to the method described by Hummel [43] and modified according to Popescu et al. [12]. Lipase (EC 3.1.1.3) activity was determined using the Lipase Activity Colorimetric Assay Kit instructions (code K 722; Bio Vision, Milpitas, CA, USA). Maltase (EC 3.2.1.20) activity was measured using a commercial kit, following the manufacturer's instructions (Maltase assay kit, My BioSource, San Diego, CA, USA). The enzymatic activity of invertase (EC 3.2.1.26) was determined according to the Invertase assay kit instructions (code MAK 118; Sigma-Aldrich, Darmstadt, Germany). Endo- $\beta$-1,4-glucanase (EC 3.2.1.4) activity was assayed according to the method described by Ahmed et al. [44] and Lokapirnasari et al. [45] using DNS reagent and carboxymethyl cellulose $(\mathrm{CMC})$ as the substrate. Specific activities for amylase are expressed as micromoles of maltose released in one minute at $25^{\circ} \mathrm{C}$ per milligram of protein; those for trypsin are expressed as micromoles of $N$ - $p$-Tosyl-L-arginine methyl ester hydrochloride (TAME) hydrolyzed in one minute at $25^{\circ} \mathrm{C}$ per milligram of protein; those for lipase are expressed as the amount of enzyme that hydrolyzes triglyceride to yield $1 \mu \mathrm{mol}$ of glycerol per minute at $37^{\circ} \mathrm{C}$ per gram of protein; those for maltase are expressed as micrograms of glucose released per minute at $37^{\circ} \mathrm{C}$ per milligram of protein; those for invertase are expressed as nanomoles of glucose released per minute per milligram of protein; and those for endo- $\beta-1,4$-glucanase are expressed as one micromole of glucose released in one minute per gram of protein at $50{ }^{\circ} \mathrm{C}$. The protein concentration of the samples was calculated by interpolating in a bovine serum albumin (BSA) standard curve using the Bradford method [46]. 


\subsection{Microbiome Characterization}

After chickens were sacrificed, samples of cecal contents were collected from each experimental batch ( $n=10$ animals per group). The changes in the microbiome were assessed by the qRT-PCR technique as described by Popescu et al. [12]. The primer sequences used are shown in Table 1, and Eubacteria primers were used as internal control.

Table 1. Primers used in this study (Hayashi, Matsuki).

\begin{tabular}{cc}
\hline Taxonomic Target & Primer Sequence \\
\hline Eubacteria & UniF340 ACT CCT ACG GGA GGC AGC AGT \\
Ruminococcus & UniR514 ATT ACC GCG GCT GCT GGC \\
& Fwd ACTGAGAGGTTGAACGGCCA \\
Enterobacteriaceae & Uni515F GTG CCA GCM GCC GCG GTAA \\
& Ent826R GCC TCA AGG GCA CAA CCT CCA AG \\
Clostridium leptum & Fwd GCACAAGCAGTGGAGT \\
Rev CTTCCTCCGTTTTGTCAA & Fwd GAC GCC GCG TGA AGG A \\
Clostridium cocoides & Rev AGC CCC AGC CTT TCA CAT C \\
& Fwd CCT ACG ATG GAT AGG GGT T \\
Bacteroides & Rev CAC GCT ACT TGG CTG GTT CAG \\
& LabF362 ACG AGT AGG GAA ATC TTC CA \\
Lactobacilli & LabR677 CAC CGC TAC ACA TGG AG \\
\hline
\end{tabular}

\subsection{Statistical Analysis}

All the data are expressed as mean \pm standard deviation $(n=10)$. Unpaired t-test, followed by Bonferroni's post hoc test, was performed (GraphPad Prism software, version 6) to investigate the statistical differences between the control and $\mathrm{E}$ groups for all parameters analyzed. $p$-values of $<0.05$ were considered statistically significant.

\section{Results}

\subsection{Composition Analysis of Flaxseed Meal}

Analyzing Table 2, it can be observed that the flaxseed meal used in broiler diets was a rich source of crude protein (33.29\%) and polyunsaturated fatty acids $(73.65 \%)$, especially alpha-linolenic acid $(55.93 \%)$, with an ideal PUFA n6/n3 ratio of 0.31 [47]. The results obtained in this study are similar to those reported by Panaite et al. [48], Akhtar et al. [49], and Vlaicu et al. [50] regarding the flaxseed meal's chemical composition.

\subsection{Performance Parameters}

The results regarding the production parameters recorded during the entire experimental period (1-42 days) are shown in Table 3. The inclusion of flaxseed meal in the broilers' diets did not influence their feed conversion ratio, average daily weight gain, or, consequently, general body weight. The results of the current study are in agreement with those of Konieczka et al. [51] and Turcu et al. [40]. They reported statistically insignificant results in the use of flaxseed meal in broiler diets regarding effects on rearing parameters (feed intake, body weight gain, and feed conversion ratio) during the overall feeding trials.

\subsection{Histology of the Duodenum}

The villi and intestinal crypts of the duodenal segments of chickens fed with flaxseed meal had a histological appearance similar to that for the control group, with normal columnar epithelium and mucous cells (colored in blue in AB), producing a protective layer that lines the surface of the epithelium (Figure 1). The histomorphometric analysis of the duodenum showed that the flaxseed meal supplementation to the basal diet of broiler chickens increased $(p<0.001$, Table 4$)$ the villus height, crypt depth, and villus height/crypt depth ratio compared with those of the control. 
Table 2. Nutrient contents of the flaxseed meal.

\begin{tabular}{|c|c|}
\hline Specification & Flaxseed Meal \\
\hline \multicolumn{2}{|c|}{ Proximate chemical composition (\%) } \\
\hline Dry matter, \% & $91.06 \pm 0.438$ \\
\hline Organic matter, $\%$ & $85.92 \pm 0.354$ \\
\hline Crude protein, \% & $33.29 \pm 1.570$ \\
\hline Gross fat, $\%$ & $13.90 \pm 0.438$ \\
\hline Fiber, $\%$ & $9.62 \pm 0.028$ \\
\hline Ash, \% & $5.15 \pm 0.092$ \\
\hline \multicolumn{2}{|c|}{ Fatty acid profoiles ( $\mathrm{g} \%$ of total fat) } \\
\hline Miristic acid, (C14:0) & $0.08 \pm 0.007$ \\
\hline Pentadecanoic acid, (C15:0) & $0.17 \pm 0.028$ \\
\hline Palmitic acid, (C16:0) & $4.69 \pm 0.403$ \\
\hline Palmitoleic acid, (C16:1) & $0.10 \pm 0.021$ \\
\hline Heptadecanoic acid, (C17:0) & $0.36 \pm 0.035$ \\
\hline Stearic acid, (C18:0) & $2.49 \pm 0.265$ \\
\hline Oleic acid, (C18:1) & $18.29 \pm 0.537$ \\
\hline Linoleic acid, (C18:2n6) & $16.83 \pm 0.576$ \\
\hline Arachidic acid, (C20:0) & $0.14 \pm 0.028$ \\
\hline Linolenic $\gamma$ acid, (C 18:3n6) & $0.21 \pm 0.014$ \\
\hline Linolenic acid, (C18:3n3) & $55.93 \pm 0.539$ \\
\hline Octadecatetraenoic acid, (C18:4n3) & $0.14 \pm 0.010$ \\
\hline Eicosatrienoic acid, (C20:2n6) & $0.13 \pm 0.027$ \\
\hline Eicosatrienoic acid, (C20:3n6) & $0.06 \pm 0.021$ \\
\hline Eicosatrienoic acid, (C20:3n3) & $0.05 \pm 0.014$ \\
\hline Arachidonic acid, (C20:4n6) & $0.11 \pm 0.010$ \\
\hline Docosadienoic acid, (C22:2n6) & $0.09 \pm 0.014$ \\
\hline Docosatetraenoic acid, (C22:4n6) & $0.10 \pm 0.014$ \\
\hline Other fatty acids & $0.24 \pm 0.069$ \\
\hline SFAs & $7.92 \pm 0.120$ \\
\hline MUFAs & $18.39 \pm 0.516$ \\
\hline PUFAs & $73.65 \pm 1.089$ \\
\hline n3 & $56.12 \pm 0.559$ \\
\hline & $17.53 \pm 0.940$ \\
\hline n6/n3 & $0.31 \pm 0.028$ \\
\hline
\end{tabular}

SFAs-sum of saturated fatty acids; PUFAs—sum of polyunsaturated fatty acids; n3-sum of omega 3 polyunsaturated fatty acids $(\mathrm{C} 18: 3 \mathrm{n} 3+\mathrm{C} 18: 4 \mathrm{n} 3+\mathrm{C} 20: 3 \mathrm{n} 3) ; \mathrm{n} 6$ - sum of omega 6 polyunsaturated fatty acids $(\mathrm{C} 18: 2 \mathrm{n} 6+\mathrm{C}$ $18: 3 \mathrm{n} 6+\mathrm{C} 20: 2 \mathrm{n} 6+\mathrm{C} 20: 3 \mathrm{n} 6+\mathrm{C} 20: 4 \mathrm{n} 6+\mathrm{C} 22: 2 \mathrm{n} 6+\mathrm{C} 22: 4 \mathrm{n} 6)$. All data are reported as mean \pm standard deviation of three replicate analysis.

Table 3. Production parameters throughout the experimental period (1-42 days).

\begin{tabular}{cccc}
\hline Parameter & C Experimental Diet $^{\mathbf{1}}$ & $p$-Value \\
\hline Initial body weight (14 days), g & $506.71 \pm 29.70$ & $506.53 \pm 51.73$ & 0.9852 \\
Final body weight (42 day), g & $3163.45 \pm 315.84$ & $3136.67 \pm 346.47$ & 0.7534 \\
Body weight gain, g & $2656.75 \pm 309.96$ & $2630.12 \pm 363.60$ & 0.7166 \\
Average daily gain, g & $91.61 \pm 10.69$ & $90.69 \pm 12.54$ & 0.7189 \\
Averahe daily feed intake, g & $150.96 \pm 34.19$ & $148.54 \pm 30.37$ & 0.7767 \\
Feed/gain ratio & $1.65 \pm 0.44$ & $1.64 \pm 0.40$ & 0.9680 \\
\hline
\end{tabular}

${ }^{1} \mathrm{C}$-Control diet; E—diet supplemented with flaxseed meal (4\%); $n=50$.

Table 4. Measurements of the duodenal villus height and crypt depth for the control and experimental groups.

\begin{tabular}{cccc}
\hline Parameter & Control & Dietary Treatment & $\boldsymbol{p}$-Value \\
\hline Villus height $(\mu \mathrm{m})$ & $848 \pm 33.2$ & $1148 \pm 29.1^{* * *}$ & $1.01 \times 10^{-12}$ \\
Crypt depth $(\mu \mathrm{m})$ & $145 \pm 7.4$ & $164 \pm 6^{* * *}$ & $1.90 \times 10^{-5}$ \\
Villus height/crypt depth & $5.9 \pm 0.4$ & $7.0 \pm 0.3^{* * *}$ & $1.18 \times 10^{-5}$ \\
\hline
\end{tabular}

C group: basal diet/control group; E group: flaxseed meal supplementation to the basal diet of broiler chickens. All data are reported as mean values \pm standard deviation (SD) and statistical significance, where ${ }^{* * *} p<0.001$. 

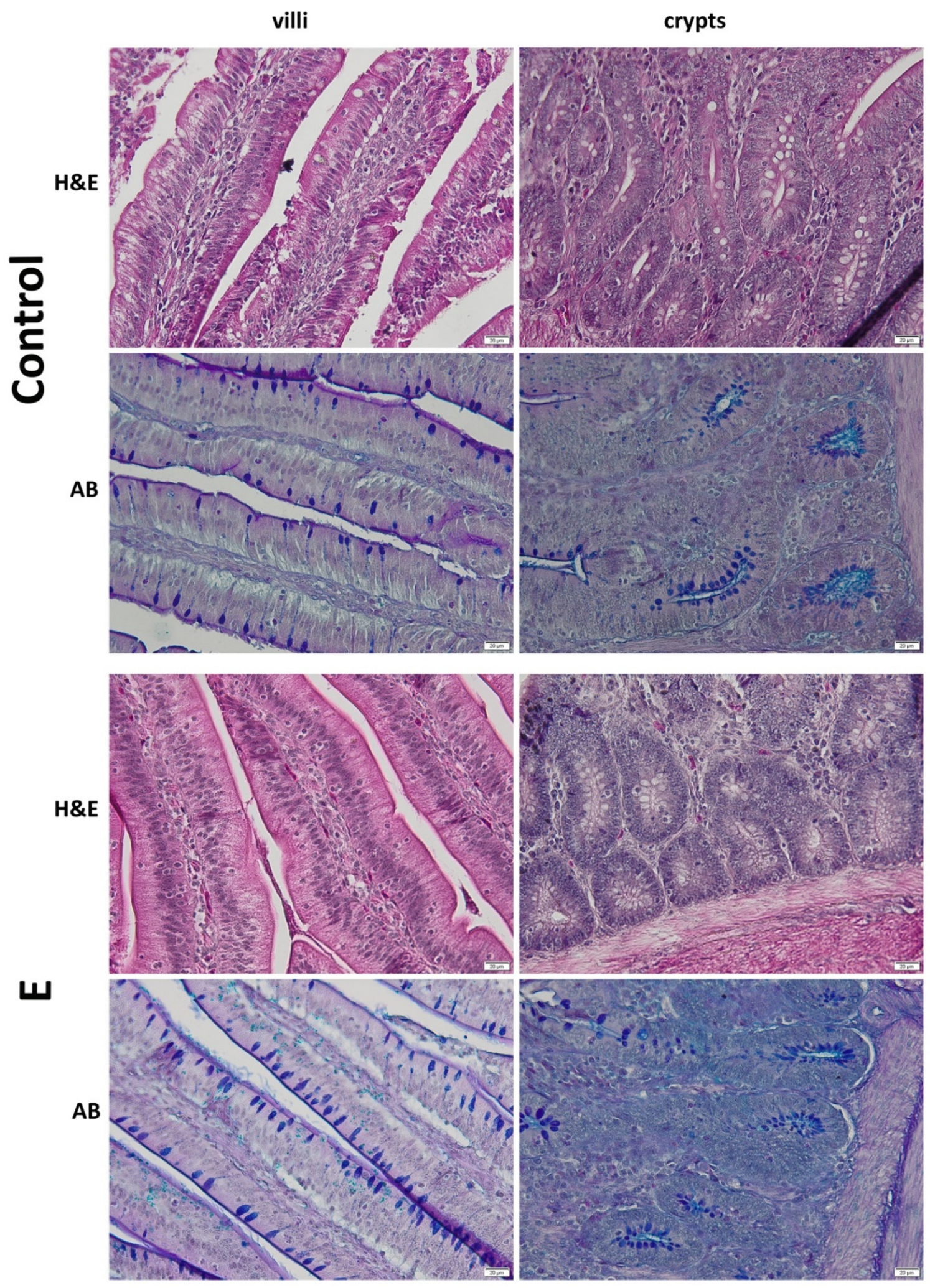

Figure 1. Histological aspects of the duodenal villi and crypts for the control and experimental (E) groups via hematoxylin and eosin (H\&E) and Alcian blue (AB) staining. Scale bar $=20 \mu \mathrm{m}$.

\subsection{Histology of the Jejunum}

The histological aspect of the jejunum for the experimental group harbored a normal aspect similar to that for the control group in terms of epithelial and mucous cells in the villi, as well as crypt cells (Figure 2). The histomorphometric analysis of the jejunum showed that 
the flaxseed meal supplementation to the basal diet of broiler chickens increased $(p<0.001$, Table 5) the villus height, crypt depth, and villus height/crypt depth ratio compared with those of the control.
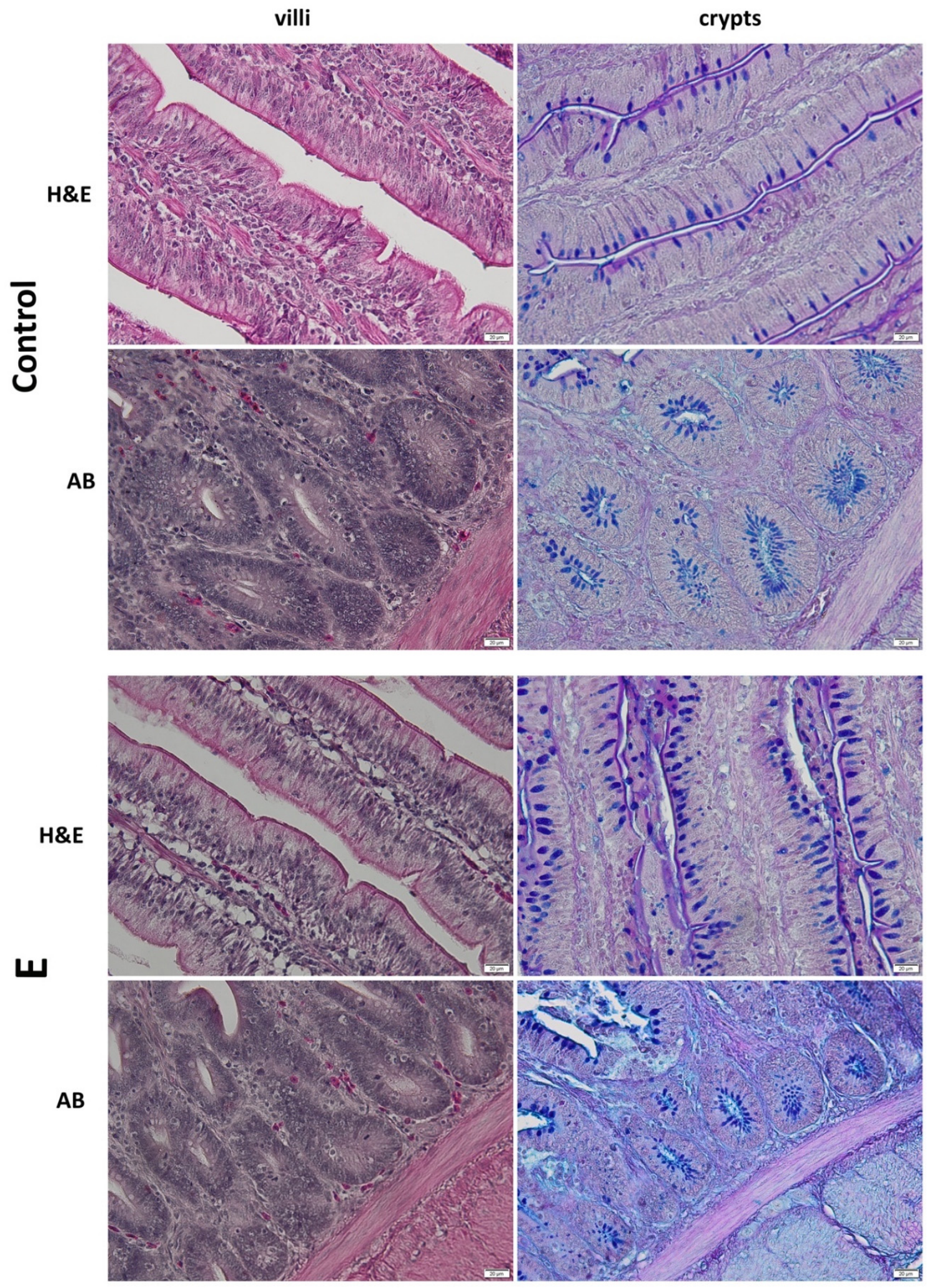

Figure 2. Histological aspects of the jejunal villi and crypts for the control and experimental (E) groups via hematoxylin and eosin (H\&E) and Alcian blue (AB) staining. Scale bar $=20 \mu \mathrm{m}$. 
Table 5. Measurements of the jejunal villus height and crypt depth for the control and experimental groups.

\begin{tabular}{cccc}
\hline Parameter & Control & Dietary Treatment & $p$-Value \\
\hline Villus height $(\mu \mathrm{m})$ & $935 \pm 25.6$ & $1251 \pm 14.4^{* * *}$ & $1.72 \times 10^{-13}$ \\
Crypt depth $(\mu \mathrm{m})$ & $152 \pm 7.4$ & $174 \pm 3.5^{* * *}$ & $5.45 \times 10^{-6}$ \\
Villus height/crypt depth & $6.2 \pm 0.3$ & $7.2 \pm 0.2^{* * *}$ & $3.95 \times 10^{-6}$ \\
\hline
\end{tabular}

C group: basal diet/control group; E group: flaxseed meal supplementation to the basal diet of broiler chickens. All data are reported as mean values \pm standard deviation (SD) and statistical significance, where ${ }^{* * *} p<0.001$.

\subsection{Intestinal Enzyme Activities}

In the duodenum, maltase activity decreased significantly by $42 \%$ for the E group (133 $\mathrm{U} / \mathrm{mg})$ compared to the control $(232 \mathrm{U} / \mathrm{mg})$. In the jejunum, maltase enzymatic activity increased significantly by $52 \%$ in the case of the E group ( $494 \mathrm{U} / \mathrm{mg})$ compared to the control (325 $\mathrm{U} / \mathrm{mg}$ ) (Figure 3). The specific activity of duodenal invertase was significantly increased by $46 \%$ in the E group $(14 \mathrm{U} / \mathrm{mg})$, whereas in the jejunum, it increased significantly by almost $227 \%(24 \mathrm{U} / \mathrm{mg})$ compared to the control $(7.28 \mathrm{U} / \mathrm{mg})$.

\section{DUODENUM}

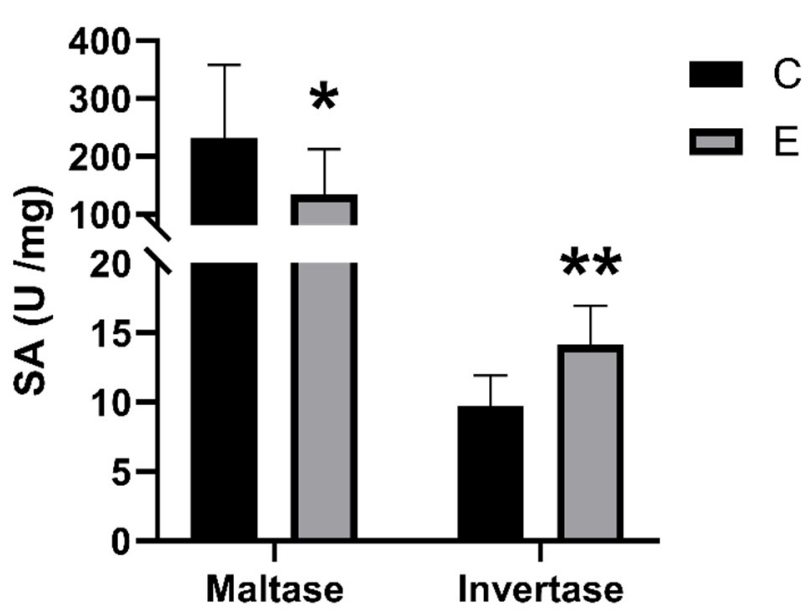

JEJUNUM

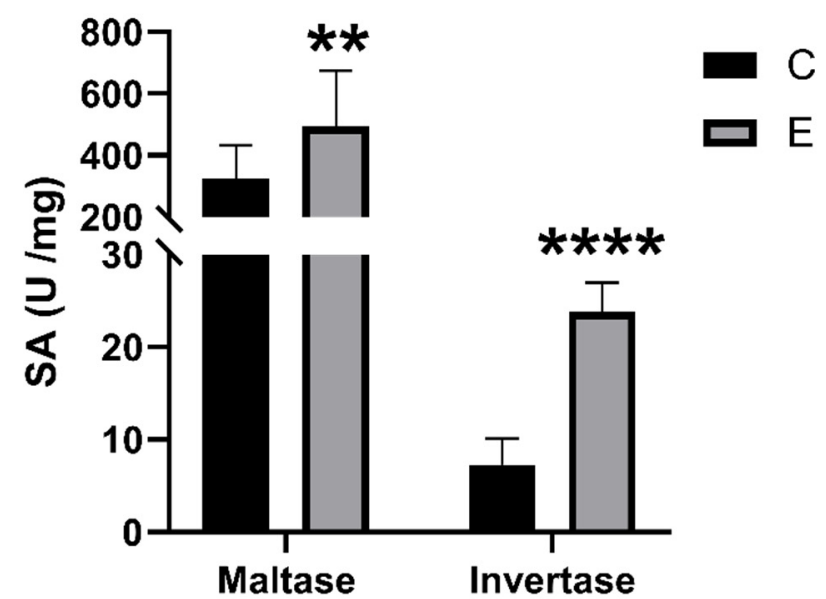

Figure 3. Effect of flaxseed meal supplementation to the basal diet of broiler chickens on the enzymatic specific activity (SA) of maltase and invertase, expressed as units per milligram of protein, from the duodenum and jejunum mucosa. All data are reported as mean values \pm standard deviation (SD), and statistical significance is indicated as follows: ${ }^{*} p \leq 0.05$; ${ }^{* *} p \leq 0.01 ;{ }^{* * * *} p \leq 0.0001(n=10)$.

Our experimental data revealed an insignificant increase by 2.3 times in the specific activity of alpha-amylase in the duodenum intestinal contents of the E group $(0.094 \mathrm{U} / \mathrm{mg})$ as compared to the control $(0.041 \mathrm{U} / \mathrm{mg})$. In the jejunum, the same enzymatic activity increased significantly by $38 \%$ in the case of the E group $(0.7 \mathrm{U} / \mathrm{mg})$ compared to the control (0.5 U/mg) (Figure 4).

The specific activity of trypsin in the duodenum was insignificantly decreased by $30 \%$ in the E group $(0.048 \mathrm{U} / \mathrm{mg})$ compared to the control $(0.069 \mathrm{U} / \mathrm{mg})$. In contrast, the administration of the basal diet enriched with $4 \%$ flaxseed meal increased trypsin activity insignificantly by $71 \%$ in the jejunum $(0.08 \mathrm{U} / \mathrm{mg})$. The enzymatic activity of lipase in the duodenum was decreased by $19 \%$ in the $\mathrm{E}$ group $(3.15 \mathrm{U} / \mathrm{mg})$ compared to the control level $(3.88 \mathrm{U} / \mathrm{mg})$. Moreover, the enzymatic activity of endo- $\beta-1,4$-glucanase from both intestinal segments was increased by $83 \%$ in the duodenum $(0.0062 \mathrm{U} / \mathrm{mg})$ and significantly increased in the jejunum $(0.001 \mathrm{U} / \mathrm{mg})$ by $357 \%$ of the control group level in the experimental group (Figure 4). 

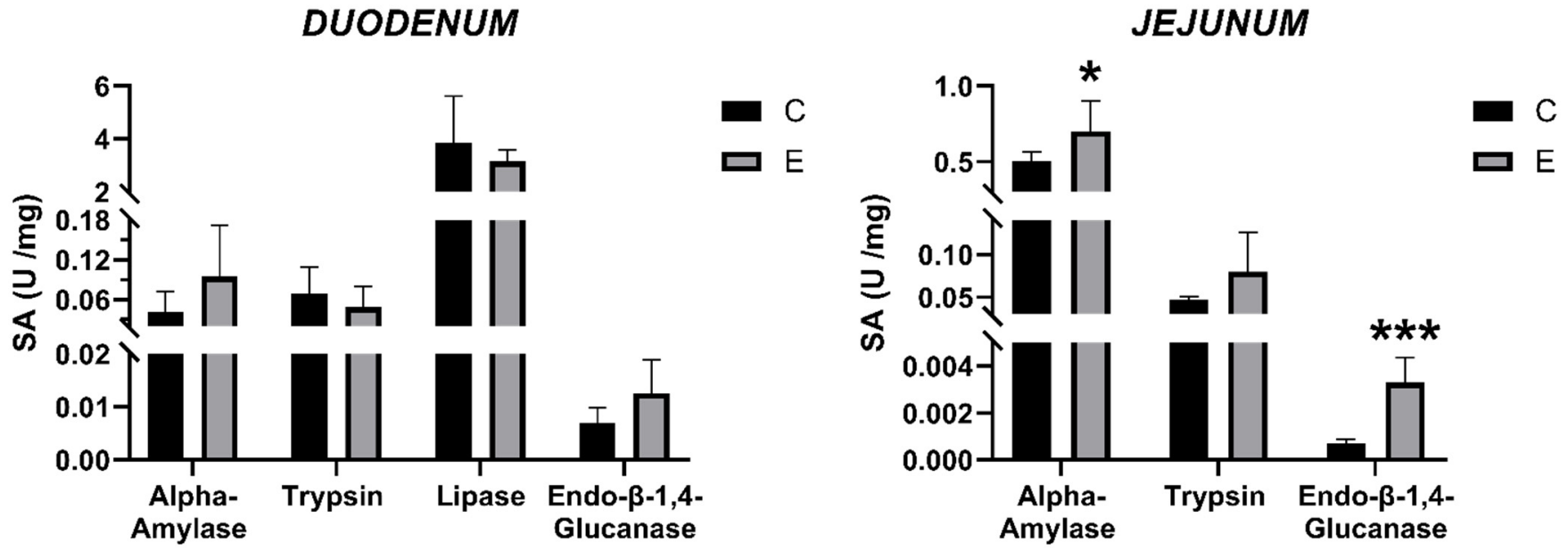

Figure 4. Effect of flaxseed meal supplementation to the basal diet of broiler chickens on the enzymatic specific activity (SA) of alpha-amylase, trypsin, lipase, and endo- $\beta$-1,4-glucanase, expressed as units per milligram of protein, from the duodenum and jejunum intestinal contents. All data are reported as mean values \pm standard deviation (SD), and statistical significance is indicated as follows: ${ }^{*} p \leq 0.05 ;{ }^{* *} p \leq 0.001(n=10)$.

\subsection{Intestinal Microbiome}

Poultry diet exerts a crucial effect on the gut microbiome in terms of diversity and composition. Compared to the conventional diet, the one enriched with flaxseed meal did not produce significant microbiome changes in terms of the relative abundance of taxa such as Bacteroides spp., Ruminococcus spp., Enterobacteriaceae, or Clostridium leptum (Figure 5).

\section{MICROBIOME CHANGES}

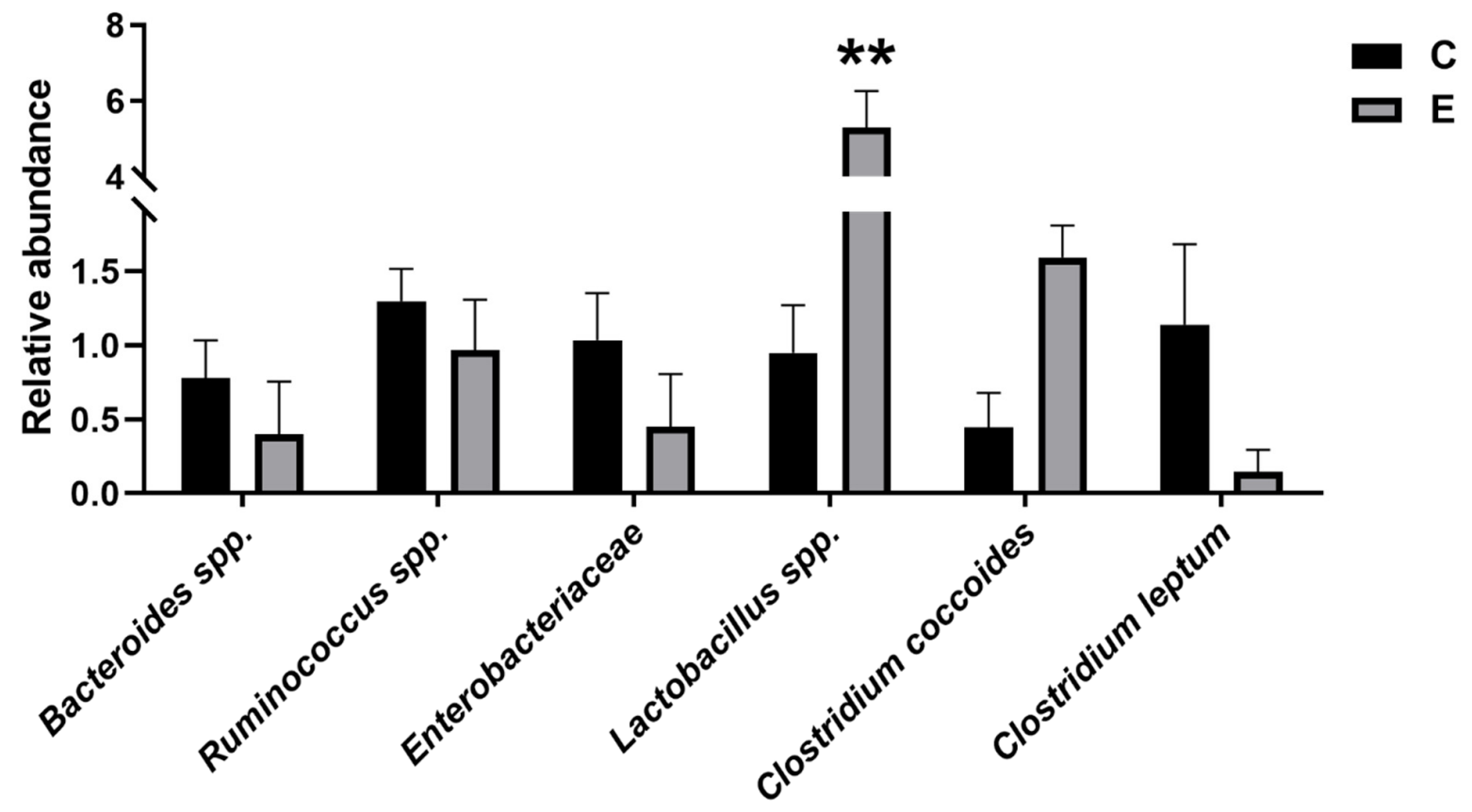

Figure 5. Microbiome changes induced by flaxseed meal administration in broilers $(n=10)$ determined by qRT-PCR using primers for $16 \mathrm{~S}$ rDNA. Statistical significance is indicated as ${ }^{* *} p \leq 0.01$.

Flaxseed meal administration led to a low abundance of the Clostridium leptum group by $87 \%$ ( 0.147 relative abundance), but this was not statistically significant. Nevertheless, flaxseed meal administration led to a significant enrichment in Lactobacillus spp. by 5.6 times (5.310 relative abundance, $p$ value $=0.0043$, Mann-Whitney test, data point distribution 
for normalization was analyzed using the Kolmogorov-Smirnov test), a group of bacteria known to be probiotics.

\section{Discussion}

The intestinal nutrient uptake is highly dependent upon the interaction between digestive secretions and the condition of the absorptive surface [52]. We show here that flaxseed meal supplementation had beneficial effects in the duodenum and the jejunum morphology, characterised by a significant increase in villus height, probably leading to increased nutrient adsorption. Absorptive efficiency is controlled by the characteristics of the intestinal absorptive surface [53]. Morphologically, crypt depth and intestinal villus length are indicative of the intestinal absorptive capacity. High intestinal villus length triggers an increase in the mucosal surface area, which, in our study, may be due to the PUFA composition of flaxseed meal, as previously reported [54].

Digestion mediates the relation between animals and their environment [55]. Indeed, the digestive system's efficiency in extracting energy from nutrients is influenced by hydrolysis rates, fermentation and absorption digesta retention times, and the gastrointestinal tract's surface area and volume [56].

The enterocyte membrane-bound enzymes hydrolyze food molecules that arrive in the small intestine [57] from the upper digestive segments [56]. Increased effectiveness of birds' endogenous enzymes allows for the gel forms characteristic of soluble fibers to be broken down more efficiently, hence improving starch, protein, fat, and amino acid digestibility $[35,58]$.

Amylase acts on starch, catalyzing hydrolysis of the $\alpha 1-4$ glycosidic bond, generating maltose as an end product and thereby improving its digestibility. In our study, the activity of alpha-amylase was increased in the duodenum and jejunum when compared to that for the control group. This could be due to the important content of linoleic acid in the flaxseeds, a potent activator of amylase secretion by pancreatic acinar cells [59]. On the other hand, oleic and linoleic acids showed an important inhibitory action against $\alpha$-glucosidase activity [60]. This could explain the decrease in maltase activity in the duodenum, even as the villus length increased. In the jejunum, this enzymatic activity was higher in the E group as compared to control one, this being correlated with the greater villus length. Probably due to the high secretion of amylase, its activity in the duodenum was also inhibited to a certain extent, but it remained a little bit higher than that in the control group. The other brush border disaccharidase, i.e., invertase, which catalyzes the hydrolysis of the $\alpha$ 1-2 glycosidic bond between an $\alpha$ glucose unit and a $\beta$ fructose one, showed increased activity in both analyzed intestinal segments, suggesting a direct correlation between the enzyme molecules and the increasing length of the villi in the $\mathrm{E}$ group compared to the control group.

Trypsin is a proteolytic enzyme that hydrolyses protein and peptides and accounts for most peptidase activity of the brush border membrane [56]. In our study, there was no significant variation of trypsin activity in the duodenum and jejunum in group E compared to the control group. Our results regarding this enzyme activity were in agreement with those of Attia et al. [61], showing that the free fatty acid content does not interfere with its pancreatic secretion and/or activity.

Lipids are the main energy source for broilers [62] and enter the duodenum intact. The presence of food in this part of the intestine stimulates the secretion of cholecystokinin, triggering the contraction of the gall bladder and exocrine pancreas secretion. In the presence of bile acids, micelles are formed, which are probably composed mainly of PUFAs. Lipase acts at the lipid-water interface of micelles, being stabilized by colipase [63]. According to our data, there was no significant difference between the lipase specific activity levels in the $\mathrm{E}$ and control groups. This could be due to the fact that colipase stabilizes the micelles and extremely diminishes the hydrolysis rate of triacylglycerols, such that the possible differences could no longer be observable [64]. This lack of variation in the lipase activity in group E could be the reason for the lack of weight gain. Our results 
are different from those reported by Polycarpo et al. [65], who used soy oil as a source of PUFAs.

Gram-positive bacteria from the intestinal microbiome, such as Lactobacillus spp. and Bifidobacterium spp., are able to produce glycosyl hydrolases for digesting dietary nutrients and producing valuable metabolites [66]. The endo- $\beta-1,4$-glucanase catalyzes hydrolysis polysaccharides containing a 1,4- $\beta$-glucan backbone from a range of materials and is produced by both prokaryote and eukaryote organisms [67].

Our results showed that endo- $\beta-1,4$-glucanase activity from the duodenum and jejunum was higher in the E group as compared to the control group, which strongly correlates with the significant enrichment in Lactobacillus spp. from the cecal microbiome. Data regarding the intestinal microbiome indicated that flaxseed meal used as a feed additive in poultry may harbor prebiotic effects, triggering the expansion of beneficial members of the microbiome. Probiotics induce physiological changes in the intestinal tissue, culminating in immunological changes that augment the animal's resistance to pathogens. Moreover, probiotics themselves produce short organic fatty acids (butyrate, acetate, propionate) and metabolites with antimicrobial activity (i.e., reactive oxygen species, lactic acid, bacteriocins, etc.) [68]. Previously, it was shown that oleic acid had a protective effect on the survival of lactobacilli [69], which could explain the important increase in the Lactobacillus spp. population in the cecum.

The abundance of Clostridium coccoides is positively associated with a high intake of MUFAs and PUFAs [70] and the composition of flaxseed meal used in this study (Table 3). Furthermore, flaxseed meal with high content of fiber and n-3 PUFAs [25] exerts a protective effect when included in the diet in the case of the development of inflammatory bowel disease. Previous research found that an appropriate n-6/n-3 PUFAs ratio in the diet is essential, the former being an anti-inflammatory molecule and the latter being proinflammatory [71]. Dietary flaxseed meal supplementation that contains a high level of n-3 PUFAs in chickens' diets has an anti-inflammatory effect, significantly reducing spleen cytotoxic T-cell activity in comparison with diets containing $70 \mathrm{~g} / \mathrm{kg}$ corn oil or lard [72].

Moreover, a high-fat diet can lead to a reduction in Enterobacter spp. and Clostridium leptum and an increase in Lactobacillus spp. [73], as shown in Figure 5 for the diet supplemented with flaxseed meal (group E).

Respondek at al. [74] showed that the presence of C18 hydroxy-monoenoic fatty acids was positively correlated with an increase in the Clostridium coccoides population and negatively with the Clostridium leptum population, which supports the microbiome changes (Figure 5) in accordance with the fatty acid profile from flaxseed meal (Table 3).

\section{Conclusions}

Our study shows that supplementation of the basal diet of Cobb 500 broiler chickens with flaxseed meal, rich in linolenic, linoleic, and oleic acids, modulated the enzymatic activities of $\alpha$-amylase maltase and invertase. Moreover, there was an increase in the villus height and crypt depth as a result of the diet enriched with flaxseed oil, which can increase the surface area and absorption capacity of the small intestine. The end products of these enzymatic activities, as well as all PUFAs, sustained the increase in the Lactobacillus spp. population, which is a mark of a healthy microbiome. This was correlated with the endo- $\beta$ 1,4-glucanase activity in the duodenum and jejunum. Even if this feed supplementation did not induce weight gain in the chickens, their health quality was probably improved.

Author Contributions: Conceptualization, A.D. and T.D.P.; methodology, R.G.P.; S.N.V.; G.G.P.; R.P.T. and S.G.; software, R.G.P.; validation, R.G.P.; S.N.V. and G.G.P.; formal analysis, R.G.P. and S.N.V.; investigation, R.G.P.; S.N.V.; G.G.P.; S.G.; R.P.T. and A.H.; resources, A.D.; data curation, R.G.P.; writing—original draft preparation, A.D.; A.H.; R.G.P.; T.D.P. and G.G.P. writing-review and editing, A.D.; S.E.G., S.N.V. and G.G.P.; visualization, A.H.; supervision, A.D. and S.N.V.; project administration, T.D.P. and S.E.G.; funding acquisition, S.N.V. and A.H. All authors have read and agreed to the published version of the manuscript. 
Funding: This research was funded by a grant from the Romanian Minister of Research and Innovation, CCCDI-UEFISCDI, project number PN-III-P1-1.2-PCCDI-2017-0473/“From classical animal nutrition to precision animal nutrition, scientific foundation for food security", within PNCDI III.

Institutional Review Board Statement: The study was conducted according to the guidelines of the Declaration of Helsinki and approved by the Institutional Review Board (or Ethics Committee) of National Research and Development Institute for Animal Biology (IBNA Balotești)-(Approval ID. 52/30.07.2014).

Data Availability Statement: The data presented in this study are available on request from the corresponding author. The data are not publicly available due to privacy reasons.

Acknowledgments: This work was supported by a grant from the Romanian Minister of Research and Innovation, CCCDI-UEFISCDI, project number PN-III-P1-1.2-PCCDI-2017-0473/“From classical animal nutrition to precision animal nutrition, scientific foundation for food security", within PNCDI III "Poultry feeding-A natural way of maintaining gut health, poultry performance, and food quality under conditions imposed by the ban of antibiotics".

Conflicts of Interest: The authors declare no conflict of interest. The funders had no role in the design of the study; in the collection, analyses, or interpretation of data; in the writing of the manuscript; or in the decision to publish the results.

\section{References}

1. Statista. Available online: https://www.statista.com/statistics/237637/production-of-poultry-meat-worldwide-since-1990/ (accessed on 26 March 2021).

2. Wong, J.T.; Bruyn, J.; De Bagnol, B.; Grieve, H.; Li, M.; Pym, R.; Alders, R.G. Small-scale poultry and food security in resource-poor settings: A review. Glob. Food Sec. 2017, 15, 43-52. [CrossRef]

3. Barton, M.D. Antibiotic use in animal feed and its impact on human health. Nutr. Res. Rev. 2021, 61, 279-299. [CrossRef]

4. Zhou, Y.; Li, Y.; Zhang, L.; Wu, Z.; Huang, Y.; Yan, H.; Zhong, J.; Wang, L.J.; Abdullah, H.M.; Wang, H.H. Antibiotic Administration Routes and Oral Exposure to Antibiotic Resistant Bacteria as Key Drivers for Gut Microbiota Disruption and Resistome in Poultry. Front. Microbiol. 2020, 11, 1319. [CrossRef]

5. Hassan, M.A.; Masud, I.A. An overview of the hepatoprotective potentials of Phyllanthus amarus. J. Pharmacogn. Phytochem. 2018, 7, 2777-2782.

6. Svihus, B. Function of the digestive system. In Informal Nutrition Symposium. J. Appl. Poult. Res. 2014, 23, 306-314. [CrossRef]

7. Tallentire, C.W.; Leinonen, I.; Kyriazakis, I. Breeding for efficiency in the broiler chicken: A review. Agron. Sustain. Dev. 2016, 36, 66. [CrossRef]

8. Shafey, T.M.; Mahmoud, A.H.; Hussein, E.; Suliman, G.; Shafey, T.M.; Mahmoud, A.H.; Hussein, E.; Suliman, G. The Performance and Characteristics of Carcass and Breast Meat of Broiler Chickens Fed Diets Containing Flaxseed Meal chickens fed diets containing flaxseed meal. Ital. J. Anim. Sci. 2016, 13, 3514. [CrossRef]

9. Sugiharto, S. Role of nutraceuticals in gut health and growth performance of poultry. J. Saudi Soc. Agric. Sci. 2016, 15, 99-111. [CrossRef]

10. Yadav, S.; Jha, R. Strategies to modulate the intestinal microbiota and their effects on nutrient utilization, performance, and health of poultry. J. Anim. Sci. Biotechnol. 2019, 9, 1-11. [CrossRef]

11. Adedokun, S.A.; Olojede, O.C. Optimizing Gastrointestinal Integrity in Poultry: The Role of Nutrients and Feed Additives. Front. Vet. Sci. 2019, 5, 348. [CrossRef]

12. Popescu, R.G.; Voicu, S.N.; Pircalabioru, G.G.; Gharbia, S.; Hermenean, A.; Georgescu, S.E.; Panaite, T.D. Effects of Dietary Inclusion of Bilberry and Walnut Leaves Powder on the Digestive Performances and Health of Tetra SL Laying Hens. Animals 2020, 10, 823. [CrossRef]

13. Alagawany, M.; Elnesr, S.S.; Farag, M.R. The role of exogenous enzymes in promoting growth and improving nutrient digestibility in poultry. Iran. J. Vet. Res. 2018, 19, 157-164.

14. Recoules, E.; Lessire, M.; Labas, V.; Duclos, M.J.; Lardic, L. Digestion dynamics in broilers fed rapeseed meal. Sci. Rep. 2019, 28, 3052. [CrossRef]

15. Alshamy, Z.; Richardson, K.C.; Hu, H.; Hafez, H.M. Comparison of the gastrointestinal tract of a dual-purpose to a broiler chicken line: A qualitative and quantitative macroscopic and microscopic study. PLoS ONE 2018, 13, e0204921. [CrossRef]

16. Lan, Y.; Verstegen, M.W.A.; Tamminga, S.; Williams, B.A. The role of the commensal gut microbial. Worlds Poult. Sci. J. 2005, 61, 95-104. [CrossRef]

17. Leeming, E.R.; Johnson, A.J.; Spector, T.D.; Le Roy, C.I. Effect of Diet on the Gut Microbiota: Rethinking Intervention Duration. Nutrients 2019, 11, 2862. [CrossRef] [PubMed]

18. Cencic, A.; Chingwaru, W. The role of functional foods, nutraceuticals, and food supplements in intestinal health. Nutrients 2010, 2, 611-625. [CrossRef]

19. Lutful Kabir, S.M. The role of probiotics in the poultry industry. Int. J. Mol. Sci. 2009, 10, 3531-3546. [CrossRef] 
20. Král, M.; Angelovi, M.; Mrázová, L'. Application of Probiotics in Poultry Production. Anim. Sci. Biotechnol. 2012, 45, 55-57, ISSN 2344-4576.

21. Jha, R.; Das, R.; Oak, S.; Mishra, P. Probiotics (Direct-Fed Microbials) in Poultry Nutrition and Their Effects on Nutrient Utilization, Growth and Laying Performance, and Gut Health: A Systematic Review. Animals 2020, 10, 1863. [CrossRef]

22. Gadde, U.; Kim, W.H.; Oh, S.T.; Lillehoj, H.S. Alternatives to antibiotics for maximizing growth performance and feed efficiency in poultry: A review. Anim. Health Res. Rev. 2017, 18, 26-45. [CrossRef]

23. Stevanović, Z.D.; Bošnjak-Neumüller, J.; Pajić-Lijaković, I.; Raj, J.; Vasiljević, M. Essential Oils as Feed Additives-Future Perspectives. Molecules 2018, 23, 1717. [CrossRef]

24. Gheisar, M.M.; Kim, I.H. Phytobiotics in poultry and swine nutrition-A review. Ital. J. Anim. Sci. 2018, 17, 92-99. [CrossRef]

25. Kajla, P.; Sharma, A.; Sood, D.R. Flaxseed-a potential functional food source. J. Food Sci. Technol. 2015, 52, 1857-1871. [CrossRef] [PubMed]

26. Cherian, G.; Quezada, N. Egg quality, fatty acid composition and immunoglobulin Y content in eggs from laying hens fed full fat camelina or flax seed. J. Anim. Sci. Biotechnol. 2016, 7, 15. [CrossRef] [PubMed]

27. Pirmohammadi, A.; Khalaji, S.; Yari, M. Effects of Linseed Expansion on its Dietary Molecular Structures, and on Broiler Chicks Digestive Enzymes Activity, Serum Metabolites, and Ileal Morphology. J. Appl. Poult. Res. 2019, 28, 997-1012. [CrossRef]

28. Collins, T.F.; Sprando, R.L.; Black, T.N.; Olejnik, N.; Wiesenfeld, P.W.; Babu, U.S.; Bryant, M.; Flynn, T.J.; Ruggles, D.I. Effects of flaxseed and defatted flaxseed meal on reproduction and development in rats. Food Chem. Toxicol. 2003, 41, 819-834. [CrossRef]

29. Conforti, F.D.; Cachaper, K.F. Effects of selected antioxidants on physical and sensory characteristics of yeast bread containing flaxseed meal. Int. J. Consum. Stud. 2009, 33, 89-93. [CrossRef]

30. Aziza, A.E.; Panda, A.K.; Quezada, N.; Cherian, G. Nutrient digestibility, egg quality, and fatty acid composition of brown laying hens fed camelina or flaxseed meal. J. Appl. Poult. Res. 2013, 22, 832-841. [CrossRef]

31. Shahid, M.S.; Raza, T.; Wu, Y.; Hussain Mangi, M.; Nie, W.; Yuan, J. Comparative Effects of Flaxseed Sources on the Egg ALA Deposition and Hepatic Gene Expression in Hy-Line Brown Hens. Foods 2020, 9, 1663. [CrossRef]

32. Beheshti Moghadam, M.; Cherian, G. Use of flaxseed in poultry feeds to meet the human need for n-3 fatty acids. Worlds Poult. Sci. J. 2017, 73, 803-812. [CrossRef]

33. Zuidhof, M.J.; Betti, M.; Korver, D.R.; Hernandez, F.I.; Schneider, B.L.; Carney, V.L.; Renema, R.A. Omega-3-enriched broiler meat: 1. Optimization of a production system. Poult. Sci. 2009, 88, 1108-1120. [CrossRef]

34. Apperson, K.D.; Cherian, G. Effect of whole flax seed and carbohydrase enzymes on gastrointestinal morphology, muscle fatty acids, and production performance in broiler chickens. Poult. Sci. 2017, 96, 1228-1234. [CrossRef]

35. Raza, A.; Bashir, S.; Tabassum, R. An update on carbohydrases: Growth performance and intestinal health of poultry. Heliyon 2019, e01437. [CrossRef] [PubMed]

36. Stillhart, C.; Vučićević, K.; Augustijns, P.; Basit, A.W.; Batchelor, H.; Flanagan, T.R.; Gesquiere, I.; Greupink, R.; Keszthelyi, D.; Koskinen, M.; et al. Impact of gastrointestinal physiology on drug absorption in special populations-An UNGAP review. Eur. J. Pharm. Sci. 2020, 147, 105280. [CrossRef]

37. Mir, N.A.; Tyagi, P.K.; Biswas, A.K.; Tyagi, P.K.; Mandal, A.B.; Wani, M.A.; Deo, C.; Biswas, A.; Verma, A. Performance and meat quality of broiler chicken fed a ration containing flaxseed meal and higher dietary lysine levels. J. Agric. Sci. 2018, 156, 291-299. [CrossRef]

38. Untea, A.E.; Varzaru, I.; Panaite, T.D.; Gavris, T.; Lupu, A.; Ropota, M. The Effects of Dietary Inclusion of Bilberry and Walnut Leaves in Laying Hens' Diets on the Antioxidant Properties of Eggs. Animals 2020, 10, 191. [CrossRef]

39. Panaite, T.D.; Criste, R.D.; Olteanu, M.; Untea, A.E.; Ropota, M.; Varzaru, I.; Lupu, A. Feeding value of local phyto-additives, potential ingredients in poultry diets. Sci. Papers Ser. D Anim. Sci. 2020, LXII, 1-8, ISSN 2393-2260.

40. Turcu, R.P.; Panaite, T.D.; Untea, A.E.; Soica, C.; Iuga, M.; Mironeasa, S. Effects of Supplementing Grape Pomace to Broilers Fed Polyunsaturated Fatty Acids Enriched Diets on Meat Quality. Animals 2020, 10, 947. [CrossRef]

41. NRC, National Research Council. Nutrient Requirements for Poultry, 9th ed.; National Academy Press: Washington, DC, USA, 1994.

42. Bernfeld, P. Amylases: Alpha and beta methods. Enzymology 1995, 1, 149-158.

43. Hummel, B.C.W. A modified spectrophotometric determination of chymotrypsin, trypsin and thrombin. Can. J. Biochem. Physiol. 1959, 37, 1393-1399. [CrossRef]

44. Ahmed, I.; Zia, M.; Iqbal, H. Bioprocessing of Proximally Analyzed Wheat Straw for Enhanced Cellulase Production through Process Optimization with Trichodermaviride under SSF. IJBSE 2010, 4, 119-125.

45. Lokapirnasari, W.P.; Nazar, D.S.; Nurhajati, T. Supranianondo, K.; Yulianto, A.B. Production and assay of cellulolytic enzyme activity of Enterobacter cloacae WPL 214 isolated from bovine rumen fluid waste of Surabaya abbatoir, Indonesia. Vet. World 2015, 8, 367-371. [CrossRef]

46. Bradford, M.M. A rapid and sensitive for the quantitation of microgram quantities of protein utilizing the principle of protein-dye binding. Anal. Biochem. 1976, 72, 248-254. [CrossRef]

47. Simopoulos, A.P. The importance of the ratio of omega-6/omega-3 essential fatty acids. Biomed. Pharmacother. 2002, 56, 365-379. [CrossRef]

48. Panaite, T.D.; Criste, R.D.; Ropota, M.; Criste, V.; Vasile, G.; Olteanu, M.; Vlaicu, P.A.; Socoliuc, R.P. Determination of the feeding value of food industry by-products. Sci. Pap. Anim. Sci. Ser. Lucrări Ştiinţifice Seria Zooteh. 2016, 66, 106-111. 
49. Akhtar, M.N.; Mushtaq, Z.; Ahmad, N.; Khan, M.K.; Ahmad, M.H.; Hussain, A.I.; Imran, M. Optimal Ultrasound-Assisted Process Extraction, Characterization, and Functional Product Development from Flaxseed Meal Derived Polysaccharide Gum. Processes 2019, 7, 189. [CrossRef]

50. Vlaicu, P.A.; Panaite, T.D.; Dragotoiu, D.; Ropota, M.; Bobe, E.; Olteanu, M.; Criste, R.D. Feeding quality of the meat from broilers fed with dietary food industry by-products (flaxseed, rapeseeds and buckthorn meal, grape pomace). Sci. Pap. Ser. D Anim. Sci. 2017, 60, 123-130.

51. Konieczka, P.; Czauderna, M.; Smulikowska, S. The enrichment of chicken meat with omega-3 fatty acids by dietary fish oil or its mixture with rapeseed or flaxseed-Effect of feeding duration: Dietary fish oil, flaxseed, and rapeseed and n-3 enriched broiler meat. Anim. Feed Sci. Technol. 2017, 223, 42-52. [CrossRef]

52. Metzler-Zebeli, B.U.; Magowan, E.; Hollmann, M.; Ball, M.E.E.; Molnar, A.; Witter, K.; Ertl, R.; Hawken, R.J.; Lawlor, P.G.; O'Connell, N.E.; et al. Differences in intestinal size, structure and function contributing to feed efficiency in broiler chickens reared at geographically distant locations. Poultry Sci. 2018, 97, 578-591. [CrossRef]

53. Kiela, P.R.; Ghishan, F.K. Physiology of Intestinal Absorption and Secretion. Best practice \& research. Clin. Gastroenterol. 2016, 30, 145-159. [CrossRef]

54. Adabi, S.G.; Hajibabaei, A.; Casey, N.H.; Bayraktaglu, A.G. The effect of various dietary vegetable oil sources on villi morphology and liver aldehydes in young layers. S. Afr. J. Anim. Sci. 2016, 46, 63-69. [CrossRef]

55. Barboza, P.S.; Parker, K.L.; Hume, I.D. Chapter 5. Digestive Function. In Integrative Wildlife Nutrition, 1st ed.; Barboza, P.S., Parker, K.L., Hume, I.D., Eds.; Springer: Berlin/Heidelberg, Germany, 2009; pp. 73-93. [CrossRef]

56. Ciminari, E.; Chediack, J.G. Activity of Digestive Enzymes in Chicken's Small Intestine and Caeca: Effect of Dietary Protein and Carbohydrate Content. Asian J. Poult. Sci. 2014, 8, 49-63. [CrossRef]

57. Hooton, D.; Lentle, R.; Monro, J.; Wickham, M.; Simpson, R. The Secretion and Action of Brush Border Enzymes in the Mammalian Small Intestine. Rev. Physiol. Biochem. Pharmacol. 2015, 168, 59-118. [CrossRef] [PubMed]

58. Dida, M.F. Review Paper on Enzyme Supplementation in Poultry Ration. IJBC 2016, 1, 1-7. [CrossRef]

59. Wooten, M.W.; Wrenn, R.W. Linoleic Acid is a potent activator of protein kinase C type III- $\alpha$ isoforms in pancreatic acinar cells; its role in amylase secretion. Biochem. Biophys. Res. Commun. 1998, 153, 67-73. [CrossRef]

60. Su, C.-H.; Hsu, C.-H.; Ng, L.-T. Inhibitory potential of fatty acids on key enzymes to types 2 diabetes. Biofactors $2013,39,415-421$. [CrossRef] [PubMed]

61. Attia, Y.A.; Al-Harthi, M.A.; Abo El-Maaty, H.M. The effects of Different Oil sources on Performance, Digestive Enzymes, Immunological, Antioxidant and Morphometric Responses of Broiler Chicks. Front. Vet. Sci. 2020, 7, 181. [CrossRef]

62. Hu, Y.D.; Lan, D.; Zhu, Y.; Pang, H.Z.; Mu, X.P.; Hu, X.F. Effect of diets with different energy and lipase levels on performance, digestibility and carcass trait in broilers. Asian-Australas. J. Anim. Sci. 2018, 31, 1275-1284. [CrossRef]

63. Baião, N.C.; Lara, L.J.C. Oil and Fat in Broiler Nutrition. Braz. J. Poultry Sci. 2005, 7, 129-141. [CrossRef]

64. Couëdelo, L.; Boué-Vaysse, C.; Fonseca, L.; Montesinos, E.; Djoukitch, S.; Combe, N.; Cansell, M. Lymphatic absorption of $\alpha$-linolenic acid in rats fed flaxseed oil-based emulsion. Br. J. Nutr. 2011, 105, 1026-1035. [CrossRef]

65. Polycarpo, G.V.; Cruz, V.C.; Alexandre, N.C.; Fascina, V.B.; Souza, I.M.G.P.; Cravo, J.C.M.; Albuquerque, R.; Sartori, J.R.; Pezzato, A.C. Effect of lipid sources and inclusion levels in diets for broiler chickens. Arq. Bras. Med. Vet. Zootec. 2014, 66, 519-528. [CrossRef]

66. Singh, R.P.; Rajarammohan, S.; Thakur, R.; Hassan, M. Linear and branched $\beta$-Glucans degrading enzymes from versatile Bacteroides uniformis JCM $13288^{\mathrm{T}}$ and their roles in cooperation with gut bacteria. Gut Microbes 2020, 12, 1-18. [CrossRef] [PubMed]

67. Linton, S.M. Review: The structure and function of cellulase (endo- $\beta$-1,4-glucanase) and hemicellulase ( $\beta$-1,3-glucanase and endo- $\beta-1,4$-mannase) enzymes in invertebrates that consume materials ranging from microbes, algae to leaf litter. Comp. Biochem. Physiol. B. Biochem. Mol. Biol. 2020, 240, 110354. [CrossRef]

68. Knaus, U.G.; Hertzberger, R.; Pircalabioru, G.G.; Yousefi, S.P.; Branco Dos Santos, F. Pathogen control at the intestinal mucosa$\mathrm{H}_{2} \mathrm{O}_{2}$ to the rescue. Gut Microbes 2017, 8, 67-74. [CrossRef]

69. Corcoran, B.M.; Stanton, C.; Fitzgerald, G.F.; Ross, R.P. Growth of probiotic lactobacilli in the presence of oleic acid enhances subsequent survival in gastric juice. Microbiology 2007, 153, 291-299. [CrossRef] [PubMed]

70. Jamar, G.; Santamarina, A.B.; Dias, G.C.; Masquio, D.C.L.; de Rosso, V.V.; Pisani, L.P. Relationship between fatty acids intake and Clostridium coccoides in obese individuals with metabolic syndrome. Food Res. Int. 2018, 113, 86-92. [CrossRef]

71. Parolini, C. Effects of Fish n-3 PUFAs on Intestinal Microbiota and Immune System. Mar. Drugs. 2019, 17, 374. [CrossRef] [PubMed]

72. Calder, P.C. Immunoregulatory and anti-inflammatory effects of n-3 polyunsaturated fatty acids. Braz. J. Med. Biol. Res. 1998, 31, 467-490. [CrossRef]

73. Zhang, M. A Review of the Role of Gut microbiome in Obesity. E3S Web Conf. 2020, 218, 03010. [CrossRef]

74. Respondek, F.; Gerard, P.; Bossis, M.; Boschat, L.; Bruneau, A.; Rabot, S.; Wagner, A.; Martin, J.C. Short-chain fructooligosaccharides modulate intestinal microbiota and metabolic paramet;rs of humanized gnotobiotic diet induced obesity mice. PLoS ONE 2013, 8, e71026. [CrossRef] [PubMed] 